\title{
PENGARUH PERSEPSI SISWA TENTANG KOMPETENSI GURU TERHADAP HASIL BELAJAR GAMBAR TEKNIK DAN MINAT BELAJAR SISWA TERHADAP HASIL BELAJAR GAMBAR TEKNIK SISWA KELAS XI DI SMK N 3 YOGYAKARTA
}

\author{
Arga Kuncoro Jati*\& Sukaswanto \\ Pendidikan Teknik Otomotif, Universitas Negeri Yogyakarta \\ E-mail: arga_kuncoro2016@student.uny.ac.id, sukaswanto@uny.co.id
}

\begin{abstract}
Abstrak
Penelitian ini bertujuan untuk mengetahui (1) Pengaruh Persepsi Siswa Tentang Kompetensi Guru terhadap Hasil Belajar Gambar Teknik, (2) Pengaruh Minat Belajar Siswa Terhadap Hasil Belajar Gambar Teknik Siswa Kelas XI Teknik Kendaraan Ringan di SMK N 3 Yogyakarta tahun ajaran 2018/2019. Subjek penelitian ini adalah seluruh siswa kelas XI Teknik Kendaraan Ringan di SMK N 3 Yogyakarta yang berjumlah 71 siswa. Pengumpulan data menggunakan angket, untuk Persepsi Siswa Tentang Kompetensi Guru dan Minat Belajar Siswa Pada Mata Pelajaran Gambar Teknik dan Hasil Belajar Siswa Kelas XI ajaran 2018/2019. Uji coba instrumen penelitian dilakukan di SMK N 3 Yogyakarta pada 32 siswa kelas X TKR 2. Uji persyaratan analisis meliputi linieritas dan normalitas masing-masing variabel. Uji hipotesis menggunakan hasil $r$ dan uji t. Hasil penelitian ini adalah : (1) Persepsi Siswa tentang Kompetensi Guru $\left(\mathrm{X}_{1}\right)$ berpengaruh positif terhadap Hasil Belajar Siswa (Y) sebesar 0,135. Hal ini menunjukkan semakin positif Persepsi Siswa tentang Kompetensi Guru, maka akan semakin tinggi Hasil Belajar (2) Minat Belajar Siswa $\left(\mathrm{X}_{2}\right)$ berpengaruh positif terhadap Hasil Belajar (Y) sebesar 0,096. Hal ini menunjukkan semakin tinggi Minat Belajar Siswa maka akan semakin tinggi Hasil Belajar.
\end{abstract}

Kata kunci : Hasil Belajar Siswa, Kompetensi Guru, Minat Belajar Siswa, Persepsi Siswa

\begin{abstract}
This study aims to determine (1) The Influence of Students' Perceptions About Teacher Competence on Technical Drawing Learning Outcomes, (2) The Effect of Student Learning Interest on Learning Outcomes of Technical Drawing of Class XI Light Vehicle Engineering Students at SMK N 3 Yogyakarta 2018/2019 school year. The subjects of this study were all students of class XI of Light Vehicle Engineering at SMK N 3 Yogyakarta, totaling 71 students. Data collection using a questionnaire, for Student Perceptions About Teacher Competence and Student Learning Interest in Technical Drawing Subjects and Student Learning Outcomes Class XI teaching 2018/2019. The trial of the research instrument was conducted at SMK N 3 Yogyakarta on 32 students of class X TKR 2. The analysis requirements test included the linearity and normality of each variable. Hypothesis testing uses the results of $r$ and $t$ tests. The results of this study are: (1) Students' Perceptions of Teacher Competence (X1) have a positive effect on Student Learning Outcomes (Y) of 0.135. This shows the more positive the Student's Perception about Teacher Competence, the higher the Learning Outcomes (2) Student Learning Interest (X2) has a positive effect on Learning Outcomes (Y) of 0.096. This shows the higher the Student's Interest in Learning, the higher the Learning Outcomes.
\end{abstract}

Key words : Student Learning Interests,Student Learning Outcomes, Student Perceptions, Teacher Competencies, 


\section{PENDAHULUAN}

Sumber daya manusia (SDM) yang berkualitas dan berkompeten sangat dibutuhkan saat ini. Sumber daya manusia merupakan aset yang berharga bagi sebuah negara, dalam jangka pendek maupun jangka panjang. Sumber daya manusia yang berkualitas adalah sumber daya manusia yang memiliki keahlian, pengetahuan dan etos kerja yang bagus, guna bersaing secara sehat di dunia kerja. Untuk membentuk dan mencetak sumber daya manusia yang berkualitas diperlukan adanya pendidikan. Pendidikan adalah usaha sadar dan terencana untuk mewujudkan suasana belajar dan proses pembelajaran agar peserta didik secara aktif mengembangkan potensi dirinya (Undang-Undang Nomor 20 Tahun 2003 Pasal 1 tentang Sistem Pendidikan Nasional).

Pendidikan sangat bermakna bagi kehidupan individu, masyarakat, dan suatu bangsa. Pendidikan adalah investasi sumber daya manusia jangka panjang yang bernilai bagi kelangsungan peradaban manusia di dunia. Hampir semua negara menempatkan pendidikan sebagai pada prioritas utama dalam konteks pembangunan bangsa dan negara. Hal ini dikarenakan menjadi bangsa yang maju merupakan cita-cita yang ingin dicapai oleh setiap negara di dunia.

Pendidikan memerlukan suatu sistem evaluasi guna mengukur ketercapaian tujuan yang telah dirumuskan bersama. Dari hasil evaluasi tersebut dapat diketahui sejauh mana perkembangan hasil belajar siswa. Peninjauan kembali terhadap faktor-faktor yang mempengaruhi hasil belajar siswa dirasa juga perlu agar apa yang dirumuskan dalam tujuan pembelajaran dapat tercapai. Hasil belajar yang dicapai tiap siswa antara satu dengan yang lain berbeda. Untuk mencapai hasil belajar yang diharapkan, maka perlu diperhatikan faktor-faktor yang mempengaruhi hasil belajar siswa. Menurut Slameto (1995: 54) hasil belajar siswa dapat dipengaruhi oleh dua faktor, yaitu faktor internal dan faktor eksternal. Faktor-faktor yang berasal dari dalam diri siswa (internal) pada umumnya bersifat biologis, seperti keadaan fisik, intelegensi, bakat, motivasi dan minat, dan lain sebagainya. Sedangkan faktor yang berasal dari luar diri siswa (eksternal) yaitu faktor keluarga, sekolah, masyarakat dan lingkungan pada umumnya.

Faktor internal dari siswa terdiri dari berbagai macam aspek maupun berbagai hal. Minat belajar siswa merupakan salah satu faktor internal yang timbul setelah adanya motivasi dari dalam diri siswa tersebut. Minat pada dasarnya adalah penerimaan antara diri sendiri dengan 
sesuatu di luar diri yang saling berpengaruh. Semakin kuat pengaruh tersebut, akan semakin besar dampak terhadap minatnya.

Minat belajar siswa pada mata pelajaran juga dapat mempengaruhi hasil belajar siswa. Minat yang ditunjukkan berbeda-beda tergantung penerimaan siswa tersebut. Beberapa siswa menunjukkan minat belajar yang tinggi dengan indikasi memperhatikan serta antusias selama proses pembelajaran. Sedangkan siswa yang memiliki minat belajar yang cenderung menunjukkan sikap yang negatif selama pembelajaran yang ditunjukkan rendah ditunjukkan dengan malas mengikuti pelajaran, bolos pelajaran, mengobrol dengan teman atau tidur dalam kelas.

Faktor eksternal yang mempengaruhi hasil belajar siswa juga dapat dipengaruhi oleh sekolah maupun lingkungan sekitar. Salah satunya adalah guru, yang merupakan pendidik dengan tugas utama mendidik dan mengajar siswa. Maka dari itu, guru memiliki peran paling vital dalam usaha mendidik siswa dalam mencapai hasil belajar yang diharapkan. Guru dibatasi oleh seperangkat pengetahuan, ketrampilan, dan perilaku yang harus dimiliki, dihayati dan dikuasai oleh guru yang dinamakan kompetensi.

Guru mempunyai pengaruh yang sangat tinggi dan signifikan terhadap motivasi dan hasil belajar siswa. Dengan adanya guru yang profesional dan berkualitas maka diharapkan efektifitas proses pembelajaran akan tercapai. Kunci yang harus dimiliki seorang guru adalah kompetensi (Acu S \& M. B Triyono, 2016).

Guru yang kompeten akan lebih mampu menciptakan suasana kelas yang kondusif dan nyaman untuk belajar. Dalam hal ini akan menimbulkan kesan yang menarik bagi siswa, yang selanjutnya akan mempengaruhi persepsi siswa terhadap kompetensi guru. Guru yang menyenangkan dan lebih mampu menguasai kelasnya, akan membuat belajar lebih efektif dan efisien sehingga belajar pada siswa pada tingkat pembelajaran yang diharapkan. Sehingga diharapkan materi yang diberikan bisa secara maksimal dipahami oleh siswa.

Menurut Sugihartono (2007:8) Persepsi adalah proses untuk menerjemahkan atau menginterpretasi stimulus yang masuk dalam alat indra. Dalam hal ini persepsi setiap individu dapat bersifat positif dapat pula bersifat negatif, tergantung pada pengamatan dan penilaian individu tersebut. Hal ini juga berlaku pula pada persepsi siswa tentang kompetensi guru, dapat bersifat positif dan negatif, tergantung pada pengamatan dan penilaian siswa mengenai bagaimana guru tersebut mengajar, bersikap, dan berkomunikasi. Dari persepsi tersebut dapat menghasilkan suatu tindakan atau sikap siswa terhadap guru maupun pembelajaran yang sedang berlangsung. 
Perbedaan sudut pandang pada pengamatan akan menghasilkan perbedaan persepsi. Persepsi siswa, baik berupa persepsi positif maupun negatif akan memengaruhi perilaku yang tampak di dalam maupun selama proses pembelajaran. Perilaku siswa tersebut akan menimbulkan tindakan yang tampak. Apabila seorang siswa memiliki persepsi positif terhadap guru, maka siswa akan memperlakukan guru tersebut dengan menghargai dan menghormatinya. Sebaliknya, apabila siswa memiliki persepsi negatif terhadap gurunya, maka siswa akan memperlakukan guru tersebut dengan kurang baik.

Dari data hasil observasi PPL yang dilakukan selama kurang lebih seminggu pada bulan Januari 2019, secara mengejutkan siswa menunjukan persepsi negatif terhadap guru pengampu mata pelajaran gambar teknik kelas X teknik kendaraan ringan di SMK N 3 Yogyakarta. Hal ini dapat ditunjukkan dengan minat belajar yang rendah, sehingga siswa menunjukan perilaku negatif dengan diantaranya tidur di kelas, berbicara dengan temannya, membolos, memainkan handphone, atau yang lebih memilih untuk keluar dari kelas dan sebagainya. Hal ini menunjukkan bahwa siswa kurang berminat mengikuti kegiatan belajar mengajar pada pelajaran gambar teknik, yang secara tidak langsung akan menyebabkan rendahnya hasil belajar yang diperoleh siswa.

Hasil belajar siswa kelas X pada mata pelajaran gambar teknik menunjukkan hasil belajar yang kurang memuaskan. Dapat dilihat dari silabus dengan menetapkan angka 70 pada nilai KKM. Nilai tersebut dirasa sangat kurang apabila dilihat dari akreditasi sekolah yang menyandang predikat "A". Hal ini juga sejalan apabila dilihat dari sudut pandang industri, mereka tentu saja menginginkan para calon pekerja yang berkompeten dibidangnya. Walaupun jika dilihat dari segi pendidikan, siswa kelas X belum pernah merasakan mata pelajaran gambar teknik sewaktu dibangku jenjang Sekolah Menengah Pertama.

Hasil belajar siswa juga dapat dilihat dari nilai ujian dan tes harian yang telah disepakati bersama oleh guru dan siswa. Pada kesempatan kali ini akan ditunjukkan rerata perolehan nilai siswa kelas X pada Ujian Tengah Semester pada mata pelajaran gambar teknik, sebagai berikut Tabel 1. Nilai Ujian Tengah Semester Gambar Teknik

\begin{tabular}{lccc}
\hline & Nilai Tertinggi & Nilai Terendah & Rata-rata \\
\hline X TKR 1 & 85 & 0 & 61,65 \\
X TKR 2 & 80 & 65 & 76,10 \\
X TKR 3 & 78 & 0 & 67,23 \\
X TKR 4 & 80 & 60 & 74 \\
\hline
\end{tabular}

Berikut perolehan nilai siswa kelas X pada Ujian Akhir Semester pada mata pelajaran gambar teknik : 
Tabel 2. Nilai Ujian Akhir Semester Gambar Teknik

\begin{tabular}{lccc}
\hline & Nilai Tertinggi & Nilai Terendah & Rata-rata \\
\hline X TKR 1 & 83 & 15 & 67.34 \\
X TKR 2 & 88 & 55 & 73.20 \\
X TKR 3 & 85 & 0 & 67.68 \\
X TKR 4 & 98 & 0 & 72.89 \\
\hline
\end{tabular}

\section{METODE}

Penelitian ini merupakan penelitian kuantitatif, karena penelitian ini menggunakan angka-angka dalam pengumpulan data sampai penyajian hasil penelitian. Selain itu, penelitian ini juga merupakan penelitian yang bersifat ex-post facto artinya penelitian dilakukan untuk meneliti peristiwa yang telah terjadi tanpa memberikan perlakuan terhadap variabel yang diteliti dan kemudian meruntut ke belakang untuk mengetahui faktor-faktor yang dapat menyebabkan timbulnya kejadian tersebut.

Subjek penelitian dalam penelitian ini adalah siswa kelas XI TKR di SMK N 3 Yogyakarta. Siswa kelas XI TKR terdiri dari 4 kelas dengan jumlah keseluruhan sebesar 71 siswa. Penelitian ini menggunakan teknik sampling jenuh yaitu bila semua anggota populasi digunakan sebagai sampel.

Penelitian ini dilakukan di SMK N 3 Yogyakarta yang beralamat di J1. R.W Monginsidi No. 2 Cokrodiningratan, Jetis, Kota Yogyakarta, Daerah Istimewa Yogyakarta. Penelitian ini dilaksanakan pada 28 Februari 2020.

Adapun yang menjadi variabel dalam penelitian ini adalah variabel bebas (X) dan variabel terikat (Y). Variabel bebas meliputi persepsi siswa tentang kompetensi guru $\left(\mathrm{X}_{1}\right)$ dan minat belajar siswa $\left(\mathrm{X}_{2}\right)$. Variabel terikat yaitu hasil belajar gambar teknik siswa kelas XI TKR di SMK N 3 Yogyakarta (Y).

Instrumen dalam penelitian ini adalah angket yang diharapkan akan memudahkan bagi responden untuk memberikan jawaban, karena alternatif jawaban sudah tersedia sehingga menjawabnya cukup memerlukan waktu yang singkat.

Pengujian validasi dilakukan dengan pertimbangan ahli (Judgment Expert) untuk diminta pertimbangannya apakah instrumen sudah layak digunakan atau perlu ada perbaikan. 
Penelitian ini mempunyai dua variabel bebas (independent) dan satu variabel terikat (dependent). Persepsi siswa tentang kompetensi guru sebagai variabel independent pertama $\left(\mathrm{X}_{1}\right)$, minat belajar sebagai variabel independent kedua $\left(\mathrm{X}_{2}\right)$, dan hasil belajar siswa sebagai variabel dependent $(\mathrm{Y})$. Hubungan variabel independent dan variabel dependent dapat dilihat melalui paradigma sebagai berikut :

Keterangan :

$\mathrm{X} 1$ : Persepsi siswa tentang kompetensi guru

X2 : Minat belajar siswa

Y : Hasil belajar siswa

$\longrightarrow$ : Pengaruh variabel-variabel bebas, $\mathrm{X}_{1}$ atau $\mathrm{X}_{2}$, secara individu terhadap variabel terikat

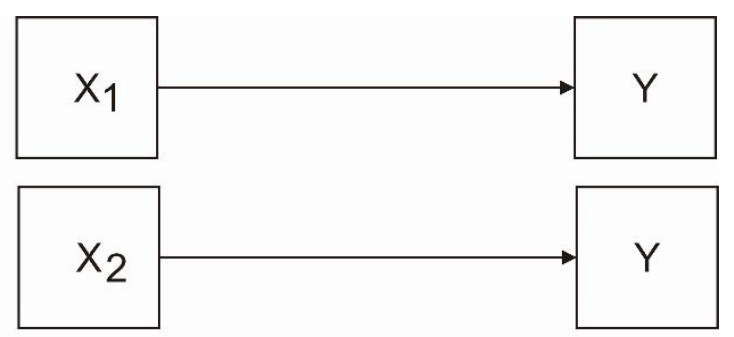

Y

Teknik analisis data meliputi dua tahapan, yaitu uji persyaratan analisis dan uji hipotesis. Uji persyaratan analisis meliputi uji linieritas dan uji normalitas. Uji hipotesis meliputi uji korelasi product moment dan uji t.

\section{HASIL PENELITIAN DAN PEMBAHASAN}

Uji linieritas ini dapat diketahui dengan menggunakan uji F. selanjutnya, harga $F$ yang diperoleh dikonsultasikan dengan harga $\mathrm{F}$ tabel. Jika $\mathrm{F}$ hitung lebih kecil atau sama dengan harga $\mathrm{F}$ tabel pada taraf signifikansi 5\%, maka hubungan variabel bebas dengan variabel terikat bersifat linier.

Tabel 3. Hasil Uji Linieritas

\begin{tabular}{lllll}
\hline Variabel & $\mathrm{F}_{\text {hit }}$ & $\mathrm{F}_{\text {tab }}$ & Sign & Ket \\
\hline $\mathrm{X} 1 \mathrm{ke} \mathrm{Y}$ & 0.725 & 1.74 & 0.827 & Linier \\
$\mathrm{X} 2$ ke $\mathrm{Y}$ & 1.276 & 1.78 & 0.240 & Linier \\
\hline
\end{tabular}

Berdasarkan tabel di atas, harga $\mathrm{F}$ hitung untuk masing-masing variabel lebih kecil dari harga $\mathrm{F}$ tabel pada taraf signifikansi 5\%, sehingga persepsi siswa tentang kompetensi guru $\left(\mathrm{X}_{1}\right)$ terhadap hasil belajar siswa (Y) bersifat linier, begitu pula minat belajar siswa kelas XI pada mata pelajaran gambar teknik $\left(\mathrm{X}_{2}\right)$ terhadap hasil belajar siswa $(\mathrm{Y})$ bersifat linier. 
Uji Normalitas adalah uji yang dilakukan dengan tujuan untuk menilai sebaran data pada sebuah kelompok data dengan maksud mengetahui sebaran data tersebut berdistribusi normal atau tidak.

Tabel 4. Hasil Uji Normalitas

\begin{tabular}{ccc}
\hline Variabel & Hasil & Keterangan \\
\hline $\mathrm{X} 1$ & 0.081 & Data berdistribusi normal \\
$\mathrm{X} 2$ & 0.200 & Data berdistribusi normal
\end{tabular}

Hasil uji normalitas untuk variabel bebas yang disajikan pada tabel di atas menunjukkan bahwa data berdistribusi normal karena hasil perhitungan mempunyai harga yang besar besar dari 0,05 .

Hipotesis merupakan jawaban sementara atas permasalahan yang dirumuskan, di mana rumusan masalah penelitian telah dinyatakan dalam bentuk kalimat pernyataan. Dikatakan sementara karena jawaban yang diberikan baru didasarkan pada teori yang relevan, belum didasarkan pada fakta-fakta empiris yang diperoleh melalui pengumpulan data.

a. Koefisien korelasi Persepsi siswa tentang kompetensi guru $\left(\mathrm{X}_{1}\right)$ terhadap Hasil Belajar Siswa $(\mathrm{Y})$

$$
\begin{gathered}
r_{x y}=\frac{\sum x y}{\sqrt{\left(\sum x^{2}\right)}\left(\sum y^{2}\right)} \\
=\frac{561,349}{\sqrt{(11841)}(1453,922)} \\
=0,135
\end{gathered}
$$

Dari hasil perhitungan dapat diketahui bahwa terdapat hubungan yang positif sebesar 0,135 antara persepsi siswa tentang kompetensi guru $\left(\mathrm{X}_{1}\right)$ dengan hasil belajar siswa pada mata pelajaran gambar teknik (Y).

b. Koefisien korelasi Minat belajar siswa (X2) terhadap Hasil Belajar Siswa (Y)

$$
\begin{gathered}
r_{x y}=\frac{\sum x y}{\sqrt{\left(\sum x^{2}\right)}\left(\sum y^{2}\right)} \\
=\frac{158,9648}{\sqrt{(1882,366)}(1453,922)}
\end{gathered}
$$




$$
=0,0961
$$

Dari hasil perhitungan dapat diketahui bahwa terdapat hubungan yang positif sebesar 0,0961 antara minat belajar siswa $\left(\mathrm{X}_{2}\right)$ dengan hasil belajar siswa pada mata pelajaran gambar teknik (Y).

Untuk membuktikan hipotesis maka dilakukan uji beda ( $t$-test) yang berfungsi untuk mencari signifikansi antar variabel yaitu variabel bebas dengan variabel tetap.

Hipotesis 1 menyatakan bahwa ada pengaruh persepsi siswa tentang kompetensi guru gambar teknik terhadap hasil belajar gambar teknik siswa kelas XI di SMK N 3 Yogyakarta. Jika diketahui sampel sebanyak 71 siswa dan korelasi antara X1 dengan Y sebesar 0,135 maka,

$$
\begin{gathered}
t=\frac{r \sqrt{n-2}}{\sqrt{1-r^{2}}} \\
t=\frac{0,135 \sqrt{71-2}}{\sqrt{1-(0,135)^{2}}} \\
t=1,131
\end{gathered}
$$

Harga $\mathrm{t}$ tersebut selanjutnya dibandingkan dengan t tabel dengan $\mathrm{dk}=\mathrm{n}-2=69$, pada taraf kesalahan 5\% dengan dk 69 maka t tabel diperoleh harga sebesar 2,000.

Hasil uji hipotesis yang dilakukan dengan uji t mendapat hasil nilai t hitung sebesar 1,131 lebih kecil dari t tabel pada taraf kesalahan 5\% sebesar 2,000 $(1,131<2,000)$, yang berarti bahwa variabel persepsi siswa tentang kompetensi guru kurang berpengaruh signifikan terhadap hasil belajar siswa.

Persepsi siswa tentang kompetensi guru kurang berpengaruh terhadap gambar teknik, hal ini menjelaskan bahwa masih banyak faktor-faktor lain yang dapat mempengaruhi hasil belajar siswa. Pada era teknologi informasi seperti sekarang, sekolah telah banyak menggunakan kurikulum 2013 yang pada dasarnya siswa dituntut untuk aktif dalam kelas dan guru menjadi tidak lagi dominan pada proses pembelajaran. Tuntutan untuk aktif dalam kelas membuat siswa mengakses berbagai sumber referensi untuk belajar, sehingga siswa memiliki persepsi positif ataupun negatif tentang kompetensi guru tidak berpengaruh signifikan terhadap hasil belajar karena siswa dapat belajar dari internet maupun media-media sejenis dimana saja dan kapan saja.

Jika dilihat dari hasil uji korelasi $\mathrm{X}_{1}$ terhadap $\mathrm{Y}$ dan juga hasil uji t menunjukkan bahwa hanya terdapat hubungan yang sangat rendah antara persepsi siswa tentang kompetensi guru terhadap hasil belajar gambar teknik siswa kelas XI di SMK N 3 Yogyakarta atau dengan kata 
lain hasil belajar gambar teknik siswa kelas XI di SMK N 3 Yogyakarta justru lebih banyak dipengaruhi oleh variabel lain yang tidak diukur dalam penelitian ini.

Hipotesis 2 menyatakan bahwa ada pengaruh minat belajar siswa terhadap hasil belajar gambar teknik siswa kelas XI di SMK N 3 Yogyakarta. Jika diketahui sampel sebanyak 71 siswa dan korelasi antara X2 dengan Y sebesar 0,096 maka,

$$
\begin{gathered}
t=\frac{0,0961 \sqrt{n-2}}{\sqrt{1-r^{2}}} \\
t=\frac{0,0961 \sqrt{71-2}}{\sqrt{1-(0,096)^{2}}} \\
t=0,801
\end{gathered}
$$

Harga $t$ tersebut selanjutnya dibandingkan dengan t tabel dengan $\mathrm{dk}=\mathrm{n}-2=69$, pada taraf kesalahan 5\% dengan dk 69 maka t tabel diperoleh harga sebesar 2,000.

Hasil uji hipotesis yang dilakukan dengan uji t mendapat hasil nilai t hitung sebesar 0,801 lebih kecil dari t tabel pada taraf kesalahan 5\% sebesar 2,000 $(0,801<2,000)$, yang berarti bahwa variabel minat belajar siswa kurang berpengaruh signifikan terhadap hasil belajar gambar teknik.

Jika dilihat dari hasil uji korelasi $\mathrm{X}_{2}$ terhadap $\mathrm{Y}$ dan juga hasil uji t menunjukkan bahwa hanya terdapat hubungan yang sangat rendah antara minat belajar siswa terhadap hasil belajar gambar teknik siswa kelas XI di SMK N 3 Yogyakarta atau dengan kata lain hasil belajar gambar teknik siswa kelas XI di SMK N 3 Yogyakarta justru lebih banyak dipengaruhi oleh variabel lain yang tidak diukur dalam penelitian ini.

Minat belajar merupakan faktor dari dalam siswa, sehingga ukuran/indikator untuk mengetahui tinggi rendahnya minat tegolong sulit, karena minat hanya terdapat dalam perasaan dan belum diekspresikan dengan tindakan. Dikarenakan minat merupakan faktor dari dalam diri dan juga program keahlian teknik kendaraan kendaraan ringan memiliki banyak mata pelajaran yang harus dikuasai oleh siswa, maka siswa tersebut cenderung untuk memilih satu atau beberapa mata pelajaran yang disukainya serta memperdalam keilmuan pada mata pelajaran tersebut.

\section{SIMPULAN}

1. Hasil perhitungan hipotesis pertama menunjukkan $t$ hitung sebesar 1,131 lebih kecil dari $t$ tabel sebesar 2,000 pada taraf signifikansi 5\%, $\mathrm{T}_{\text {hitung }}<\mathrm{T}_{\text {tabel }}(1,131<2,000)$. Hal ini juga menolak hipotesis yang menunjukkan ada pengaruh persepsi siswa tentang kompetensi 
guru gambar teknik terhadap hasil belajar gambar teknik siswa kelas XI di SMK N 3 Yogyakarta. Dapat disimpulkan bahwa persepsi siswa tentang kompetensi guru kurang berpengaruh terhadap hasil belajar siswa, karena pada era tekologi informasi seperti sekarang, siswa memiliki akses terhadap banyak sumber belajar dan guru tidak lagi menjadi dominan pada proses pembelajaran di kelas. Siswa yang memiliki persepsi negatif tentang kompetensi guru tidak berpengaruh langsung terhadap hasil belajar, karena siswa dapat belajar dimana dan kapan saja melalui internet ataupun media sejenis.

2. Hasil perhitungan hipotesis kedua menunjukkan hasil t hitung sebesar 0,801 lebih kecil dari $\mathrm{t}$ tabel sebesar 2,000 pada taraf signifikansi 5\%, $\mathrm{T}_{\text {hitung }}<\mathrm{T}_{\text {tabel }}(0,801<2,000)$. Hal ini juga menolak hipotesis yang menunjukkan ada pengaruh minat belajar siswa terhadap hasil belajar gambar teknik siswa kelas XI di SMK N 3 Yogyakarta. Minat belajar siswa pada mata pelajaran gambar teknik kurang berpengaruh secara signifikan terhadap hasil belajar gambar teknik siswa kelas XI TKR di SMK N 3 Yogyakarta pada tahun ajaran 2018/2019.

\section{DAFTAR PUSTAKA}

Presiden Republik Indonesia. (2003). Undang-Undang Republik Indonesia Nomor 20 Tahun 2003 Tentang Sistem Pendidikan Nasional. Jakarta.

Sutisna, A \& Triyono, B. M. (2016). Efektifitas Belajar Siswa Di SMK N 2 Wonosari Gunung Kidul Yogyakarta. Jurnal, JPTK FT UNY. Yogyakarta.

Slameto. (1995). Belajar dan Faktor-faktor yang Mempengaruhinya. Cet. II; Jakarta: Rineka Cipta.

Sugihartono, dkk. (2007). Psikologi Pendidikan. Yogyakarta: UNY Press. 